\title{
$\mathrm{HAP}$ 기반 네트워크에서의 EM 알고리즘을 사용한 실시간 이동 기지국 배치
}

\author{
정 웅 희 ${ }^{+} \cdot$ 송 하 윤 ${ }^{++}$
}

요 약

\begin{abstract}
$\mathrm{HAP}$ (High Altitude Platform)은 지표면 17 22km위에 있는 성층권 영역에서 운행하는 정지 궤도 공중 플랫폼으로 공중에서의 MBS(Mobile Base Station)로서의 역할이 가능하다. HAP 기반 네트워크는 인공위성 시스템과 지상통신 시스템의 장점들을 가지고 있다. 본 논문에서는 $\mathrm{HAP}$ 기반망의 구성 및 그 유지를 위한 $\mathrm{HAP} \mathrm{MBS}$ 의 배치에 대해 연구한다. 이 연구를 위해 지상 이동 노드들을 클러스터링하기 위한 클러스 터링 알고리즘이 사용되는데, 본 논문에서는 $\mathrm{EM}$ (Expectation Maximization) 클러스터링 알고리즘을 사용한다. 본 논문의 목표는 이동 통신 단 말기들 간의 거리와, 각 단말기들의 이동속도를 고려하여 단말기들이 효율적으로 클러스터링 되어 HAP의 배치가 효율적일 수 있도록 EM 알 고리즘을 적용 및 개선하고, 이 $\mathrm{EM}$ 알고리즘을 이용한 $\mathrm{HAP} \mathrm{MBS}$ 배치기법을 인구밀도에 기반을 둔 RWP(Random Waypoint) 노드 모빌리티 를 이용하여 그 성능을 평가한다.
\end{abstract}

키워드 : 이동 기지국, 성층권 통신, EM 클러스터링 알고리즘, 네트워크

\section{Realtime Mobile Base Station Placement with EM Algorithm for HAP based Network}

\author{
Woong Hee Jung ${ }^{\dagger} \cdot$ Ha Yoon Song ${ }^{+\dagger}$
}

\begin{abstract}
HAP(High Altitude Platform) is a stationary aerial platform positioned in the stratosphere between $17 \mathrm{Km}$ and $22 \mathrm{Km}$ height and it could act as an MBS (Mobile Base Station). HAP based Network has advantages of both satellite system and terrestrial communication system. In this paper we study the deploy of multiple HAP MBS that can provides efficient communication for users. For this study, EM(Expectation Maximization) clustering algorithm is used to cluster terrestrial mobile nodes. The object of this paper is improving EM algorithm into the clustering algorithm for efficiency in variety aspects considering distance between mobile terminal units and speed of mobile terminal units, and estimating performance of HAP MBS deploy technique with use of improved EM algorithm using RWP (Random Waypoint) node mobility.
\end{abstract}

Keywords: MBS, HAP Telecommunication, EM Clustering Algorithm, Network

\section{1. 서 론}

$\mathrm{HAP}$ 은 지표면 $17-22 \mathrm{Km}$ 위에 있는 성층권 영역에서 운 행하는 높은 고도에서의 플랫폼으로 $\mathrm{HAP}$ 은 지상의 기반시 설의 장점인 낮은 비용의 운영비, 낮은 전파 지연을 가지고 있고 인공위성의 고도에서의 서비스, 넓은 범위의 브로드캐

※ 본 논문은 2009학년도 홍익대학교 학술연구진흥비에 의하여 지원되었음.

† 준 회 원 : 홍익대학교 컴퓨터공학과 학사과정

†† 종신회원: 홍익대학교 컴퓨터공학과 부교수

논문접수:2009년 2월 2일

수 정 일:1차 2009년 6월 2일, 2차 2009년 7월 24일

심사완료 : 2009년 7월 28일
스트/멀티캐스트, 브로드 밴드 등의 이점들을 가지고 있으며 따라서 지상의 기반 시설과 인공위성의 장점들을 두루 가지 고 있다. 또한 $\mathrm{HAP}$ 은 쉽고, 점증적인 배치가 가능하고 지 진, 홍수 같은 재해 재난 시 지상 통신망이 붕괴 되었을 때 긴급 통신을 위해 전개가능하다. 특히 인구밀도가 적은 사막 등의 험오지, 또는 해양 등 모든 곳에 지상 기반 시설을 설치 하기 힘든 지역에서 $\mathrm{HAP}$ 을 이용하면 매우 효율적이다 [1].

$\mathrm{HAP}$ 은 독립적으로도 운영 될 수 있고 지상 기반 시설과 인공위성 시스템과 결합하여 강력한 통신 시스템을 구축할 수 있다. 그리고 $\mathrm{HAP}$ 은 그 자신이 $\mathrm{MBS}$ 로 동작하여 다수 의 사용자에게 통신을 제공할 수 있다. 여기서 지상 이동 
노드들은 그 인접도에 따라 클러스터링 되어 여러 개의 클 러스터로 분할 포함되며, 한 클러스터 당 하나의 $\mathrm{HAP}$ 이 할 당되어 해당 클러스터의 $\mathrm{MBS}$ 로서의 역할을 한다. 이러한 망 구성에서는 전체 통신망의 효율을 위해 가능한 최소 개 의 개수로, 급격한 통신 요구 변화에 따른 $\mathrm{HAP}$ 의 이동을 최소화해야 하며, ITU에서 제안한 각 $\mathrm{HAP}$ 이 서비스할 수 있는 지역 반경의 제한을 지키는 방법을 고려해야한다. 이 에 더해 추가적으로 감안해야 되는 세부적인 사항들은 [2]에 서 자세하게 논의되었다. 따라서 본 논문은 효율적인 $\mathrm{HAP}$ 배치를 위해 클러스터링 알고리즘을 사용하며 $\mathrm{K}-\mathrm{means}[3]$, $\mathrm{BIRCH}[4], \mathrm{EM}[5]$ 등의 클러스터링 알고리즘 중 $\mathrm{EM}$, 그리고 제주도 지역을 대상으로 인구 밀도 기반으로 RWP 모빌리티 를 사용한 노드 모빌리티[6]를 이용하여 구성된 통신망을 시 뮬레이션에서 나타난 각종 성능 인자를 통해서 평가한다.

본 논문의 목표는 이 $\mathrm{MBS}$ 의 실시간적인 배치가 서비스 반경 제한, 대역폭 공급 한계, 이동 거리 최소화에 따른 $\mathrm{HAP}$ 비행선 연료비용의 감축 등의 관점에서 좀 더 효율적 일 수 있는 방법론을 제시하고, 그를 실험한 결과를 분석한 다. MBS의 효율적 배치를 위한 실시간 클러스터링 알고리 즘으로 $\mathrm{EM}$ 알고리즘을 선택한 이유는 이 알고리즘이 정규 분포를 이용하기 때문에 실시간으로 안정적인 결과를 보여 준다는 점과, 이 알고리즘의 확률 초기화 값을 실시간으로 조정하면 다양한 환경에 대비할 수 있다는 점 등이다. 이는 2장에서 자세히 설명하였다. $\mathrm{EM}$ 알고리즘이 더 안정적이라 는 것은 시간에 따른 노드의 위치 변동에 의한 클러스터 중
심점의 위치 변동이 적고, 클러스터의 반경의 크기도 갑작 스러운 변동이 없다는 의미이다. 즉, 다른 클러스터링 알고 리즘, 예를 들면 $\mathrm{K}$-means 알고리즘과 같은 경우 이전 시간 의 노드들이 어느 클러스터에 속할 가능성이 얼마나 되는지 에 대한 데이터가 없기 때문에 직전의 클러스터링 결과를 세밀하게 고려하지 않은 좀 더 탐욕적인 계산 과정이 진행 되어 클러스터 중심점들의 위치가 노드 위치 변동에 따라 매번 심하게 변동된다 [7].

본 논문의 2장에서는 관련연구로서 개선된 $\mathrm{EM}$ 알고리즘 에 대한 설명, 3장에서는 성능 평가에 사용된 모빌리티에 대한 설명, 4 장에서는 시뮬레이션 결과 분석을, 5 장에서는 결론을 내린다.

\section{EM 클러스터링 알고리즘}

본 논문에서 이용할 $\mathrm{EM}$ 알고리즘[5]은, 숨겨진 데이터가 있는 상황에서 지역적인 최소값을 찾는 추정 알고리즘이며 기대(Expectation)-최대화(Maximization) 과정을 반복하며 각 클러스터의 정규 분포의 윤곽을 다져나간다 [7]. 각 클러 스터의 정규 분포는 밀도와 평균을 통하여 그 클러스터에 포함되는 노드들의 분포를 설명한다. 여기서 클러스터는 이 동 통신 기지국에 의하여 커버되는 영역을, 노드는 이동 통 신 단말기를 각각 뜻한다. 이에 대한 간략한 묘사가 지상통 신, 인공위성 시스템과의 연관된 구조와 함께 (그림 1)에 되

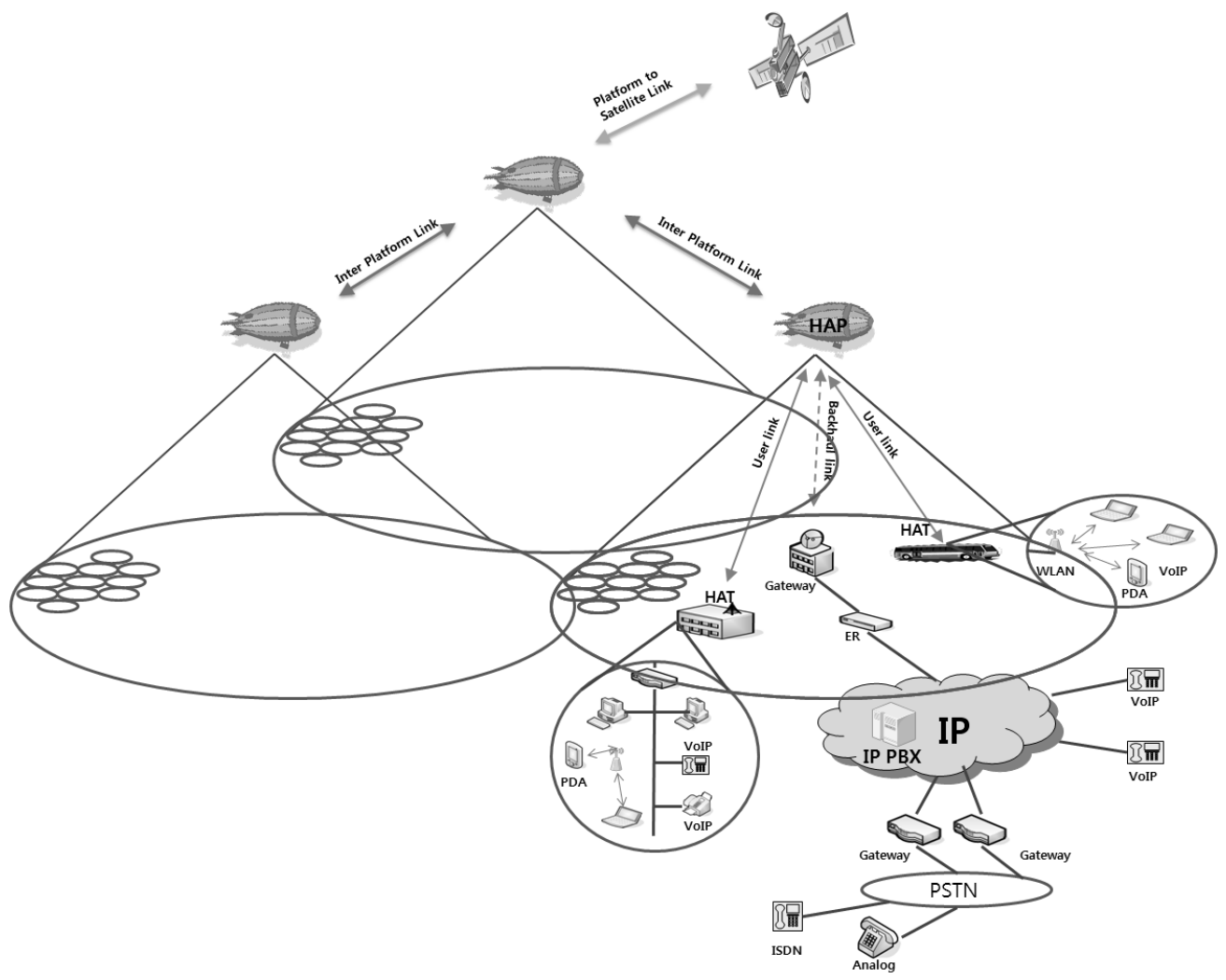

(그림 1) 지상통신, HAP, 인공위성 시스템의 통합된 구조 
어 있다. 그리고 $\mathrm{EM}$ 알고리즘에는 초기화가 필요한 값들이 있으며, 이 값들이 어떻게 정해졌는지에 따라 이 알고리즘 에 의한 클러스터링 결과가 상당히 달라진다.

$\mathrm{EM}$ 클러스터링 알고리즘의 초기화에 필요한 이 값들은 2차원 데이터이며, 이들은 각각의 노드가 각각의 클러스터 에 속할 확률이 어느 정도인가를 말해준다. 한 노드는 각 클러스터 안에 속할 가능성을 나타내는 확률 값을 모든 클 러스터에 대해 빠짐없이 가지고 있으며, 이 노드는 클러스 터링에 사용된 클러스터들의 총 개수와 동일한 개수의 값 데이터들을 가진다. 한 노드가 가지고 있는 이 값들의 합산 결과는 항상 1 이다. 이는 한 노드가 적어도 하나의 클러스 터에 속할 확률이 1 임을 의미한다. 모든 노드들은 이와 같 은 값들을 가진다. 이러한 형태로 정리되어 사용되는 $\mathrm{EM}$ 알고리즘의 초기화 값들은 어떤 관점에서 조정되었느냐에 따라 실시간 클러스터링의 결과를 달라지게 한다. 예를 들 면 지리적인 거리에 관점을 두어 확률 데이터들을 결정하면 거리에 따른 클러스터링을 진행하며, 총 단말기 사용 시간 에 관점을 두어 확률 데이터들을 결정하면 사용량에 따른 클러스터링을 진행한다. 본 논문의 4장의 결과는 실제로 그 의미가 반영된 모습을 보여준다.

본 논문은 $\mathrm{EM}$ 알고리즘의 기본 개념에 더해 $\mathrm{HAP}$ 기반 망의 클러스터링을 위해 3 가지의 추가 기능을 이용하며, 시 뮬레이션에 사용된 $\mathrm{EM}$ 알고리즘의 동작 과정은 (그림 2)와 같다. 클러스터 중심점들의 초기 배치는 초기의 한 번의 $\mathrm{K}$-means 알고리즘의 결과로 정한다. 초기화는 매 시뮬레이 션 시간마다 이루어지며, 로그 가능도(log-likelihood)의 값이 임의의 제한 값인 $\mathrm{C}$ 보다 작은 동안 $\mathrm{EM}$ 과정을 반복하고 나면 한 시각의 시뮬레이션이 끝난다. 그러고 나면 다음 시 간의 노드 위치를 재 파악하고 확률 값을 초기화하여 또다 시 이 과정을 반복한다.

3 가지의 추가적인 조정은 모두 $\mathrm{EM}$ 알고리즘의 확률 초 기화 값에 관한 것이며 첫째는, 거리에 기반을 둔 확률 초 기화를 통해 위치 문제 해결의 근본적인 거리의 속성을 고 려시킨다. 이로 인해 각 노드들은 각 클러스터에 포함될 확

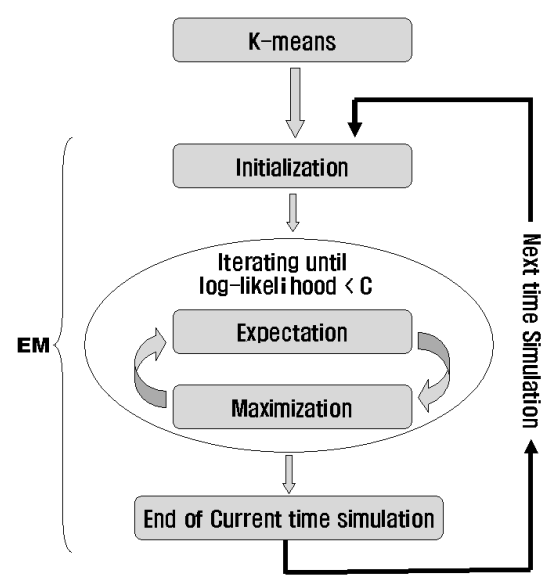

(그림 2) 본 논문에서 사용한 $\mathrm{EM}$ 알고리즘의 동작 과정
률을 결정하며, 가까운 클러스터에 속할 확률이 더 높아진 다. 구체적인 방법은 수식(1)과 같다. 여기서 $p_{n k}$ 는 $n$ 번째 노 드가 $k$ 번째 클러스터에 속하게 될 확률, $d_{n k}$ 는 $n$ 번째 노드와 $k$ 번째 클러스터의 중심점 사이의 거리, $d_{n j}$ 는 $n$ 번째 노드와 $j$ 번째 클러스터의 중심점 사이의 거리, $K$ 는 총 클러스터의 개수를 각각 뜻한다. 이를 적용한 결과는 마치 $\mathrm{K}$-means 알 고리즘의 결과와 유사하다 [7]. 초기의 클러스터의 좌표는 $\mathrm{K}$-means 알고리즘을 한번 작동시킴으로써 얻는다.

$$
p_{n k}=\frac{\frac{1}{d_{n k}}}{\sum_{j=0}^{K-1} \frac{1}{d_{n j}}}
$$

둘째는, 정규 분포 데이터를 실시간으로 유지시키는 것이 다. 이를 통해 모든 클러스터들은 이전 시간의 평균과 분산 도를 고려하여 다음 시간의 위치를 결정할 수 있기 때문에 안정적인 실시간 클러스터링이 가능하다.

셋째는, 노드 이동 속도에 따라 확률 초기화 값에 가중치 를 주는 것이다. 특정 클러스터에 포함되어 있던 어떤 노드 가 갑자기 빨라지면, 그 클러스터로부터 신뢰를 잃고 주변 의 클러스터들이 관심을 갖게 된다. 구체적인 방법은 수식 (2)와 수식(3)과 같다. 수식(2)는 확률의 감률을 정하고 있으 며, 수식(3)은 그 감률을 해당 확률 값에 적용하고 있다. 낮 아진 확률은 해당하는 노드가 해당하는 클러스터에 속할 가 능성이 더 낮아졌다는 의미를 갖는다. 수식(2)에서, $v$ 는 해 당 노드의 이동 속도, $v_{\max }$ 는 노드의 최고 이동 속도, $n$ 은 감률 함수 $f(v, n)$ 의 곡선화 정도를 각각 의미한다. (그림 3) 은 $n$ 에 의한, 감률 함수의 곡선화 정도를 보여준다. 그리고 수식(3)에서, $p_{i j}$ 는 $i$ 번 노드가 $j$ 번 클러스터에 소속될 확률, $p_{i j}{ }^{\prime}$ 는 감률에 의해 재계산된 확률을 각각 의미한다.

$$
\begin{gathered}
f(v, n)=1-\frac{v^{n}}{v_{\max }^{n}} \\
p_{i j}{ }^{\prime}=p_{i j} f\left(v_{i}, n\right)
\end{gathered}
$$

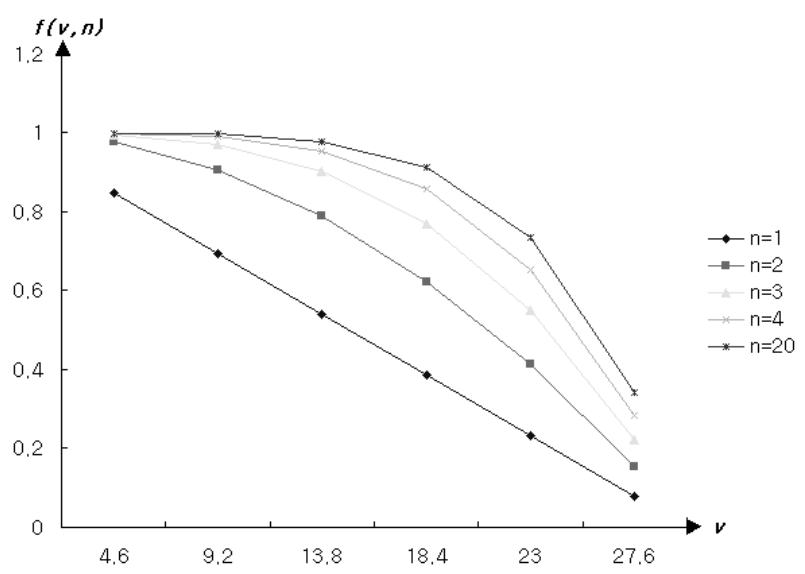

(그림 3) 감율 함수의 곡선화 조정의 정도 
그림에서 보듯이 $n$ 이 커짐에 따라, 이동 속도가 적당히 느린 노드들은 감률이 현저히 적어지며, 변곡점의 속도 이 후부터는 더 급격한 감률을 주게 되어 있다. $\mathrm{EM}$ 클러스터 링 알고리즘은 이 $n$ 값이 1 이면 이용자 단말기의 속도와 상 관없이 클러스터링을 진행하며, 반대로 $n$ 값이 너무 크면 확 률 값 자체가 거리보다 속도에 의존한 값이 되어 시간이 흐 름에 따라 클러스터링의 결과가 왜곡된다. 이는 우리가 목 표로 하는 클러스터링이 기지국과 이용자들의 지리적인 위 치를 고려하는 것이기 때문에 거리에 상관없이 과정이 진행 되면 당연히 그들의 위치를 고려하지 못한 결과가 나오게 됨을 의미한다. 그렇기 때문에 적당한 크기의 $n$ 값을 선정하 는 것이 중요하다 [7].

\section{3. 성능 평가에 사용된 노드 모빌리티}

\section{1 대상지역}

본 논문에서는 $\mathrm{EM}$ 알고리즘의 실시간적인 클러스터링의 성능 평가를 현실적인 모델에서 해 보기 위해 [6]에서 설계 및 구현한, 제주도를 기반으로 한 노드 모빌리티 모델을 사 용하였다.

\section{2 대상지역 선정이유}

노드 모빌리티의 지역으로 제주도를 선정한 이유는 첫째 로, 섬 지역으로서 제주시와 서귀포시의 특정 두 지역에 인 구가 밀집되어 있고 다른 곳은 인구 밀도가 낮다는 것과, 둘째로, 이동 통신 단말기들은 서로 이동 속도가 다른, 도보 중인 사람, 말, 자동차, 배 등에 분산되어 있다는 것이다. 셋 째로, 주변에 여러 섬들이 있으며 섬에도 이동 통신 이용자
가 있다는 점이다. 이 세 가지 점에서 볼 때 제주도는 시간 적, 공간적으로 다양한 환경을 가지고 있어 이동 기지국의 배치를 위한 클러스터링의 성능 평가를 할 수 있는 비교적 적절한 지역으로 판단되어 노드 모빌리티 지역으로 선정하 게 되었으며, 따라서 본 논문에서는 이 지역에 기반을 둔 노드 모빌리티 모델을 사용한다 [6].

\section{3 노드 모빌리티 설계 및 구현}

[6]에서 설계 구현 한 노드 모빌리티는 실제적인 제주도 인구 통계정보를 토대로 구성하였다 [8]. 여기서 설계 구현 한 노드 모빌리티의 내용은 다음 아래와 같다.

- 제주도 인구 밀도를 기준으로 15 곳을 분류하였다.

- 총 노드 수는 1120 개이다.

- 그 중 1000개 노드는 제주도에 배치 시켰다.

- 나머지 120 개 노드는 바다에 배치 시켰다.

- 노드의 종류는 사람, 배, 말, 차량 이렇게 4 가지로 구분 하였다.

여기서 노드의 초기 배치는 지역을 기반으로 하여 그 지 역에 랜덤하게 배치 시켰다. (그림 4)는 노드의 초기 배치 모습을 보여준다. 그리고 노드의 종류에 따라 속도의 범위 가 다르다. 이 자료는 <표 1>에 나와 있다. 마지막으로 이 노드 모빌리티는 일반적으로 널리 사용되는 RWP 모델을 이용하였다 [9]. 이 모빌리티의 특징은 시간에 따라 목적지 가 랜덤하게 바뀌고 속도가 정해진 범위 안에서 랜덤하게 변하는 것이다. 나머지 자세한 모빌리티 설계와 구현 내용 은 [6]에 나와 있다.

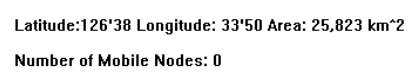

Number of Mobile Nodes: 0
Number of Cluster: 56 Number of Nodes: 1120

Max \# of Nodes in Cluster[2] : 112 Min \# of Nodes in Cluster[5] : 0
Simulation Time : 15
Average Node Speed : $0.00 \mathrm{~km} / \mathrm{h}$

Average Cluster Head Speed : $0.00 \mathrm{~km} / \mathrm{h}$

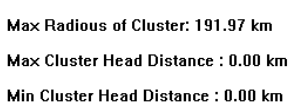

Min Cluster Head Distance : 0.00 km
Min Radious of Cluster: 0.00 km

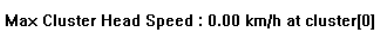

Min Cluster Head Speed $0.00 \mathrm{~km} / \mathrm{h}$ at cluster[0]

(그림 4) 초기 노드 배치 
〈표 1〉노드의 종류

\begin{tabular}{|c|c|}
\hline 노드의 종류 & 속 도 $(\mathrm{km} / \mathrm{h})$ \\
\hline \hline 사 람 & $0 \sim 10$ \\
\hline 배 & $0 \sim 40$ \\
\hline 말 & $0 \sim 40$ \\
\hline 차 량 & $0 \sim 100$ \\
\hline
\end{tabular}

\section{4. 노드 모빌리티에 EM 클러스터링 알고리즘을 적 용한 결과 분석}

2장에서 설명한 제주도 지역을 대상으로 한 노드 모빌리 티를 이용하여 $\mathrm{EM}$ 클러스터링 알고리즘을 시뮬레이션 하였 다. (그림 5)에 간략한, 시뮬레이션을 위한 프로그램 절차가 나와 있다.

위 프로그램 실행 절차에서 노드 모빌리티 모델을 NS2에 서 직접 생성 할 수 없기 때문에 먼저 $\mathrm{C}, \mathrm{C}++$ 언어를 사용 하여 $\mathrm{TCL}$ 파일을 작성하고, 그 내용을 근거로 $\mathrm{NS} 2$ 에서 Trace 파일을 생성할 수 있도록 노드 모빌리티를 설계 구현 하였다. 본 논문에서의 시뮬레이션 결과는 다음과 같은 환 경에서 진행된 것이다.

- 시간 0에서 100 까지 시뮬레이션을 하였다. 총 결과의 컷은 21개이다.

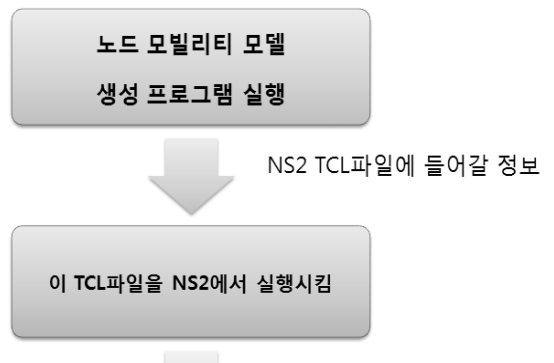

노드 움직임에 대한 Trace파일

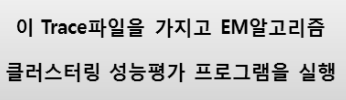

(그림 5) 시뮬레이션을 위한 프로그램 실행 절차

- 실제 성능 평가는 시간 20 에서 100 까지 하였다.

- 수식(2)의 감율 함수의 $\mathrm{n}$ 값은 3 으로 하였다. $\mathrm{n}$ 값이 3 일 때 클러스터 중심점인 클러스터 헤드의 이동률, 클 러스터의 반경의 시간의 흐름에 따른 변화율 등의 관점 에서 여러모로 가장 안정적이어 본 논문에서 선택하게 되었다.

- $\mathrm{EM}$ 클러스터링 알고리즘의 성능 평가를 다방면에서 의미 있게 하기 위해 여러 가지 인자를 사용하였다. 이 들은 <표 2>에 설명하였으며 시뮬레이션 시간에 따른

〈표 2〉성능 평가 인자

\begin{tabular}{|c|c|c|}
\hline 인 자 & 용 & 목 \\
\hline Number of Cluster & $\begin{array}{l}\text { 클러스터의 총 개수 } \\
\text { (총 노드개수/클러스터 당 평균 노드 개수) }\end{array}$ & $\begin{array}{l}\text { 클러스터는 기지국이 서비스하는 범위와 같음. } \\
\text { 기지국의 총 개수로 실시간 기지국 사용 현황을 판단. }\end{array}$ \\
\hline Number of Nodes & 지상 이동 노드의 총 개수 & $\begin{array}{l}\text { 하나의 노드는 하나의 단말기와 같음. 총 몇 개의 } \\
\text { 단말기가 서비스 되고 있는지 알아 둠. }\end{array}$ \\
\hline Number of Mobile Nodes & $\begin{array}{l}\text { 현재 움직이는 노드 개수 } \\
\text { (시뮬레이션 시간 속도가 0이상인 노드의 개수) }\end{array}$ & $\begin{array}{l}\text { 이동하는 노드의 개수. 매시간 클러스터링 결과는 } \\
\text { 이동하는 노드 개수와 상관됨. }\end{array}$ \\
\hline Max\# of Nodes in Cluster[x] & $\begin{array}{l}\text { 최대 노드 개수를 확보한 클러스터와 } \\
\text { 해당 클러스터 번호 } \mathrm{x}\end{array}$ & $\begin{array}{l}\text { 가장 무리하게 노드들을 확보 하고 있는 클러스터를 } \\
\text { 알아 냄. 기지국의 대역폭의 한계와 관계있음. 정도에 } \\
\text { 따라 추가적인 알고리즘의 필요성이 제기 될 수 있음. }\end{array}$ \\
\hline Min\# of Nodes in Cluster[x] & $\begin{array}{l}\text { 최소 노드 개수를 확보한 클러스터와 } \\
\text { 해당 클러스터 번호 } \mathrm{x}\end{array}$ & $\begin{array}{l}\text { 서비스 하고 있는 노드가 너무 적어 비용을 가장 } \\
\text { 심하게 낭비하고 있는 클러스터를 알아 냄. 기지국의 } \\
\text { 대역폭의 한계와 관계있음. 정도에 따라 추가적인 } \\
\text { 알고리즘의 필요성이 제기 될 수 있음. }\end{array}$ \\
\hline Simulation Time & 시뮬레이션 시간 & $\begin{array}{l}\text { 시뮬레이션 결과를 시간의 흐름에 따라 분석하기 } \\
\text { 위함. }\end{array}$ \\
\hline Max Radious of Cluster & 최대 클러스터 반경(단위: $\mathrm{km}$ ) & $\begin{array}{l}\text { 가장 무리한 지상의 지역적 범위를 서비스하도록 } \\
\text { 결정된 클러스터의 반경을 알아 냄. 기지국의 서비스 } \\
\text { 반경의 한계와 관계있음. }\end{array}$ \\
\hline Min Radious of Cluster & 최소 클러스터 반경(단위:km) & $\begin{array}{l}\text { 서비스 하고 있는 지상의 반경이 가장 작은 } \\
\text { 클러스터의 반경을 알아 냄. 기지국의 서비스 반경의 } \\
\text { 한계와 관계있음. }\end{array}$ \\
\hline Average Node Speed & $\begin{array}{l}\text { 평균 노드 속도 }(\mathrm{km} / \mathrm{h}) \\
\text { (각 시간 당 전체 노드 속도 합/총 노드 개수) }\end{array}$ & $\begin{array}{l}\text { 평균적으로 노드의 좌표적인 분포가 어느 정도로 } \\
\text { 변화하는지 알아 둠. 클러스터링의 실시간 안정성을 } \\
\text { 확인하기 위함. }\end{array}$ \\
\hline $\begin{array}{l}\text { Max Head Distance, } \\
\text { Max Cluster Head Speed at } \\
\text { cluster[x] }\end{array}$ & $\begin{array}{l}\text { 최대 클러스터 헤드이동거리와 해당 클러스터 } \\
\text { 속도 }(\mathrm{km} / \mathrm{h}) \text {, 클러스터 번호 X } \\
\text { (클러스터 헤드 이동거리 = 현재 클러스터 헤드 위치 - } \\
\text { 이전 클러스터 헤드 위치 })\end{array}$ & $\begin{array}{l}\text { 클러스터의 헤드는 곧 기지국이며 가장 빠르게 } \\
\text { 이동한 클러스터를 매 시간 알아 둠. 클러스터링의 } \\
\text { 실시간 안정성을 확인하기 위함. }\end{array}$ \\
\hline Average Cluster Head Speed & $\begin{array}{l}\text { 평균 클러스터 헤드 이동 속도 }(\mathrm{km} / \mathrm{h}) \\
\text { (전체 클러스터 헤드 이동속도의 합/클러스터 총 개수) }\end{array}$ & 클러스터링의 실시간 안정성을 확인하기 위함. \\
\hline $\begin{array}{l}\text { Min Head Distance, Min Cluster } \\
\text { Head Speed at cluster[x] }\end{array}$ & $\begin{array}{l}\text { 최소 클러스터 헤드이동거리와 해당 클러스터 } \\
\text { 속도 }(\mathrm{km} / \mathrm{h}) \text {, 클러스터 번호 x }\end{array}$ & 클러스터링의 실시간 안정성을 확인하기 위함. \\
\hline
\end{tabular}


Latitude:126'38 Longitude: 33'50 Area: 25,823 km² Number of Mobile Nodes: 560
Number of Cluster: 56 Number of Nodes: 1120

Max $\#$ of Nodes in Cluster[19]: 101
Min \# of Nodes in Cluster[10]: 1

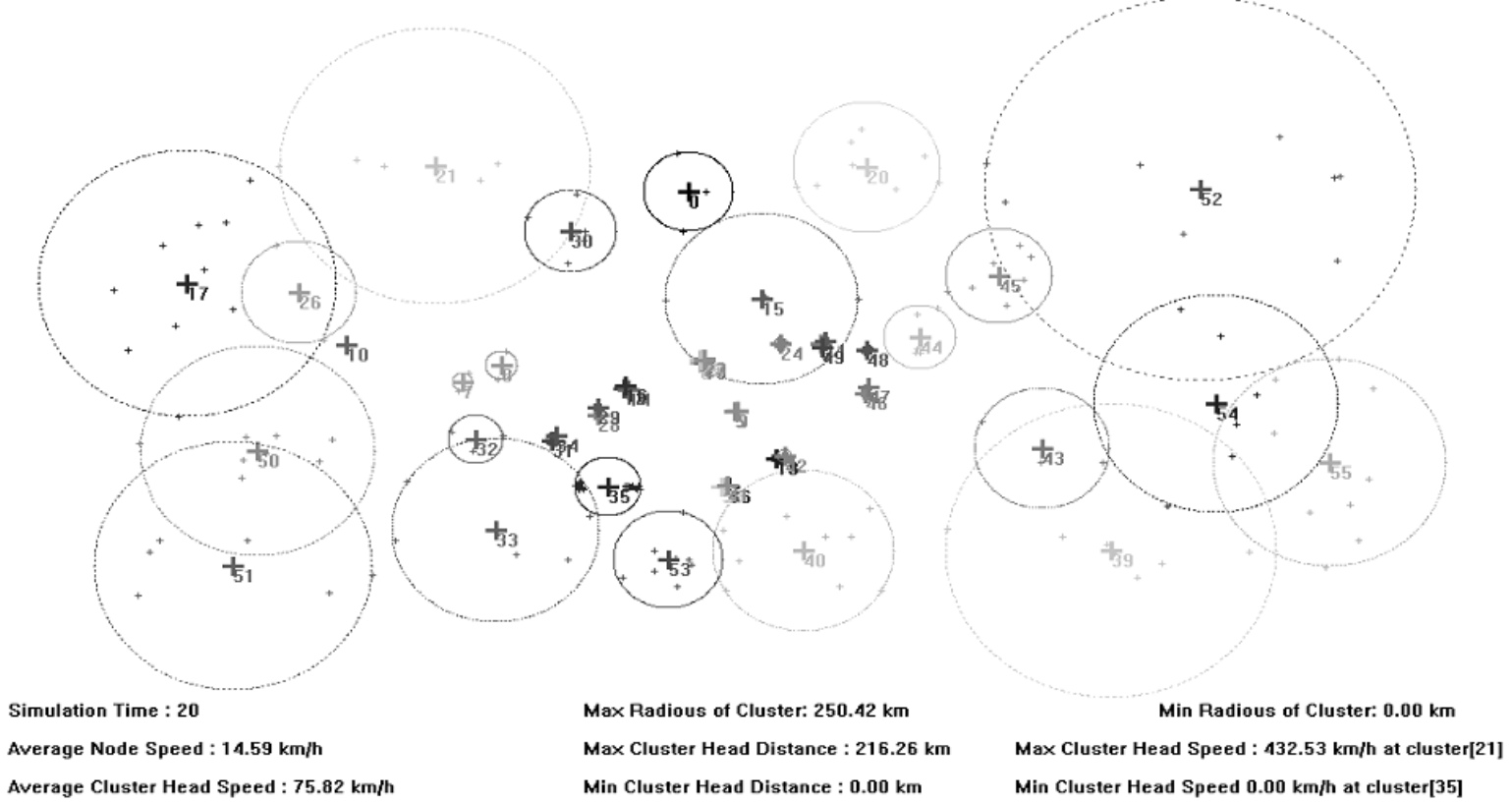

(그림 6) 시간 20일 때의 시뮬레이션 결과

클러스터 반경, 클러스터 당 노드 개수, 클러스터 헤드 속도의 세 가지 요소를 기본으로 하여 파생된 인자들 이다.

위와 같은 방법으로 다양한 성능 평가 인자를 고려하여 시뮬레이션이 진행되었고 (그림 6)와 (그림 7)은 시간 20에 서와 60 에서의 각각 $\mathrm{EM}$ 클러스터링 알고리즘을 적용한 시 뮬레이션 결과를 나타낸다. (그림 6)에서 보이는 시간 20인
시뮬레이션 초기에는 실시간 클러스터링이 안정권에 들어가 기 전의 상황을 보여준다. 이 시간대를 포함하는 초기 셋업 시간 동안은 Average Cluster Head Speed의 값이 큰 것을 보아 클러스터 헤드의 이동률이 큼을 확인할 수 있다. 하지 만 시간이 지날수록 $\mathrm{EM}$ 알고리즘은 노드 모빌리티의 속성 을 인지하고 점차 안정권으로 들어갔다. 그 근거로 (그림 7) 에서 시간 60에서의 Average Cluster Head Speed 값이 크 게 작아진 것을 확인할 수 있다.

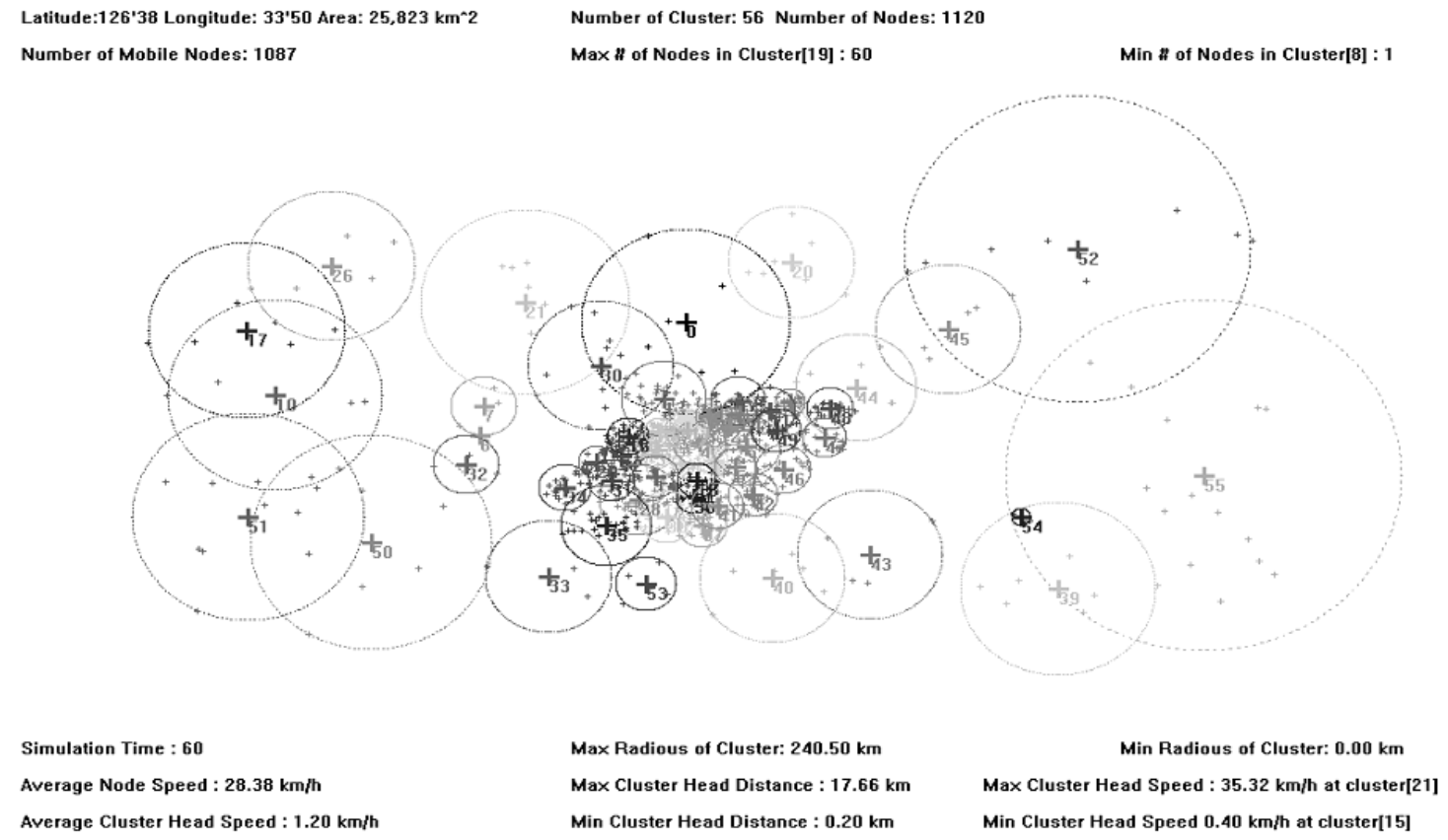

Average Cluster Head Speed : $1.20 \mathrm{~km} / \mathrm{h}$

(그림 7) 시간 60일 때의 시뮬레이션 결과 


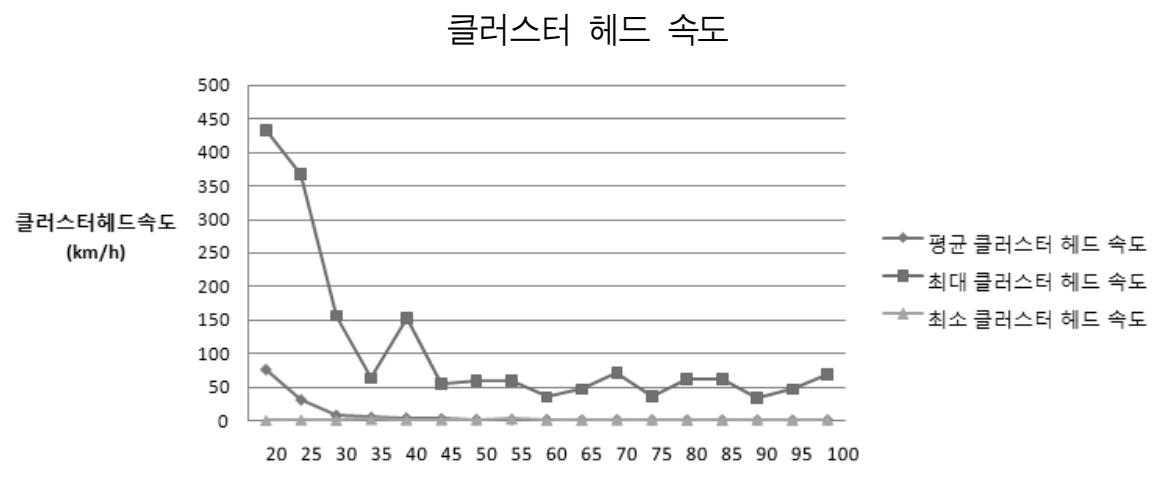

(그림 8) 시간의 흐름에 따른 클러스터 헤드 속도의 변화

$\mathrm{EM}$ 클러스터링의 초기 셋업 시간으로 판단된 시간 20 에서 45 사이 이후에는 클러스터 헤드가 평균적으로 도, 극단적으로도 안정화되는 것으로 시뮬레이션 결과가 평가되었다.

여러 가지 인자들을 고려하여 개선된 $\mathrm{EM}$ 클러스터링 알 고리즘의 성능을 평가하였으며, 그 결과는 (그림 8)과 (그림 9), 그리고 (그림 10)에 나와 있다. 이 그림들의 가로축은 시 뮬레이션 시간을 의미한다.
실시간에 따른 클러스터링 결과는 초반부의 잠깐의 큰 변 화를 가지는 결과를 거친 후에는 점차 안정화되었으며, 결 과에 대한 그림들에서 초반부의 모습을 확인할 수 있다.

(그림 8)에서는 기지국들의 위치 이동률이 점차 감소하며

클러스터 당 노드 개수

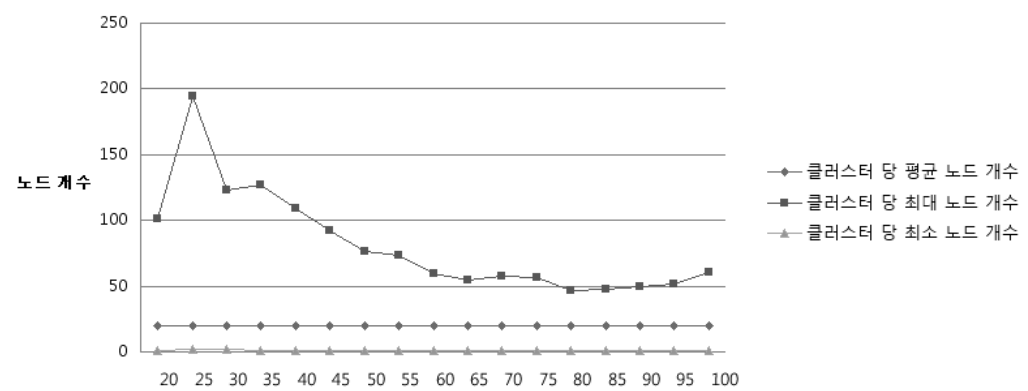

(그림 9) 시간의 흐름에 따른 클러스터 당 노드 개수 변화

초기 셋업 시간으로 보이는 시간 20에서 45사이 이후에는 클러스터 당 평균 노드 개수가 안정화되는 것으로 시뮬레이션 결과가 평가되었다.

\section{클러스터 반경}

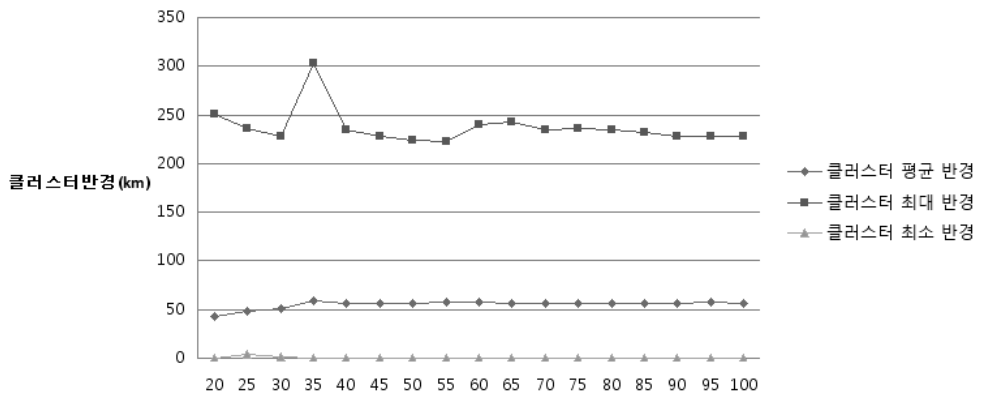

(그림 10) 시간의 흐름에 따른 클러스터 반경 변화

초기 셋업 시간으로 보이는 시간 20 에서 45 사이 이후에는 클러스터의 반경이 평균적으로 도, 극단적으로도 안정화되는 것으로 시뮬레이션 결과가 평가되었다. 
이는 비행선의 이동 비용을 줄이는 방향으로의 성과를 의미 한다. (그림 9)에서는 클러스터 당 최대 노드 개수가 줄어들 면서 각 클러스터 당 노드 개수의 범위가 줄어든 것을 확인 할 수 있다. 이는 기지국들이 이용자들을 골고루 나눠 서비 스하는 쪽으로 클러스터링 된 것으로 이해할 수 있으며, 무 리한 대역폭을 공급해야 하는 문제를 유발시키는 것과 대역 폭의 낭비 문제를 유발시키는 것을 동시에 해결하는 성과가 있음을 의미한다. (그림 10)에서 클러스터, 즉 기지국의 평균, 최대 반경이 시간의 흐름에 따라 비교적 안정화되는 모습을 보이며, 클러스터 평균 반경 수치는 ITU가 제한한 $150 \mathrm{~km}[10]$ 를 넘지 않고 있다. 즉 응용된 $\mathrm{EM}$ 알고리즘은 지상 이동 노 드의 이동성에 따라 적응적으로 클러스터링을 실시하여 $\mathrm{HAP}$ 기반망의 비교효율적인 $\mathrm{MBS}$ 배치를 가능하게 했다.

\section{5. 결론 및 향후 연구 방향}

개선된 $\mathrm{EM}$ 클러스터링 알고리즘은 본 논문에서 선정한 몇 가지 인자로 평가한 결과 몇 가지 부분에서 장점을 보였 다. 그러한 반면에, 보완해야 될 점으로서 (그림 10)에서 클 러스터의 최대 반경 수치는 $150 \mathrm{~km}$ 를 모두 넘어서고 있음이 확인되었다. 이는 반경의 제한 문제를 해결하기 위하여 별 개의 기법이 응용되어야 함을 의미한다. 이 반경 문제는 여 러 가지 발견적 방법 중 적절한 클러스터의 분할-합병을 진 행하는 방법으로 해결해 볼 수 있을 것이다. 이를 위한 좋 은 기법 중의 하나가 $\mathrm{BIRCH}$ 알고리즘의 개념이며, 본 논문 의 개선된 $\mathrm{EM}$ 클러스터링 알고리즘에 추가적으로 $\mathrm{BIRCH}$ 의 개념을 감안한 계층적인 알고리즘을 고려하고자 한다.

\section{참 고 문 헌}

[1] Karapantazis. S., Pavlidou. F.-N., "The role of high altitude platforms in beyond 3G networks," Wireless Communications, IEEE, Vol.12, Issue 6, pp.33-41, 2005.

[2] Ha Yoon Song, "A Method of Mobile Base Station Placement for High Altitude Platform based Network with Geographical Clustering of Mobile Ground Nodes," Proceedings of the International Multiconference on Computer Science and Information Technology, Vol.3, pp.869-876, 2008.

[3] J. A. Hartigan and M. A. Wong, "A k-means clustering algorithm," Appl. Statist., Vol.28, pp.100-108, 1979.

[4] 채준병, 조관식, 송하윤, "HAP 네트워크에서 $\mathrm{BIRCH}$ 클러스터 링 알고리즘을 이용한 모바일 베이스 스테이션 위치 파악," 한 국정보과학회 2008가을학술발표논문집, Vol.35, pp.185-186, 2008.
[5] Frank Dellaert, "The Expectation Maximization Algorithm," College of Computing, Georgia Institute of Technology, Machine Learning, Vol.39, Issue 2-3, pp.103-134, May-June 2000.

[6] 신영민, 조관식, 송하윤, "HAP기반 네트워크 시뮬레이션을 위 한 노드 모빌리티 구성,” 한국정보과학회 2008년 가을 학술발 표논문집, Vol.35, pp.267-272, 2008.

[7] 정웅희, 송하윤, 조관식, "HAPS 기반 네트워크에서의 실시간 이동 기지국 위치 문제 해결 정책," 제 30 회 한국정보처리학회 추계학술발표대회 논문집, 제15권, 제2호, pp.1307-1310, 2008년 11월.

[8] 제주특별자치도 홈페이지, "http://www.jeju.go.kr/contents/ index.php?mid=0109010304, 주요기본통계 자료 중 세대 및 인 구, 2007.

[9] T Camp, J Boleng, V Davies, "A survey of mobility models for ad hoc network research," Wireless Communications and Mobile Computing, 2002.

[10] S. Karapantazis, F.-N. Pavlidou, "Broadband communications via high-altitude platforms: a survey," Communications Surveys \& Tutorials, IEEE, Vol.7, Issue. 1, pp.2-31, 2005.

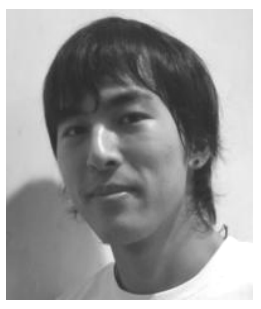

\section{정 웅 희}

e-mail :mrj16@hanmail.net

2005년 현 재 홍익대학교 컴퓨터공학과 학사과정 관심분야: 클러스터링, 실시간 정보처리

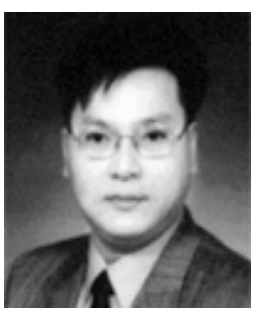

\section{송 하 윤}

e-mail : hayoon@wow.hongik.ac.kr 1991년 서울대학교 계산통계학과(학사) 1993년 서울대학교 전산과학과(석사) 2001년 University of California Los Angeles, Computer Science Department (Ph.D.) 2001년 현 재 홍익대학교 컴퓨터공학과 부교수

관심분야: 분산 센서 시스템, 고고도 네트워킹, 클러스터링 